\title{
Regulatory enzymes of carbohydrate and energy metabolism in the rabbit blastocyst ${ }^{*}$
}

\author{
Amal Mukherjee†, S. K. Deył, Jayasree Sen Guptałๆ, C. S. Ramadoss§ \\ and Z. Dickmann $\ddagger$
}

† Department of Internal Medicine, Ischemic Heart Center, University of Texas Health Science Center, Dallas, Texas 75235; $\ddagger$ Department of Gynecology \& Obstetrics, Ralph L. Smith Human

Development Research Center, University of Kansas Medical Center, Kansas City, Kansas 66103; and §Department of Biochemistry, Purdue University, West Lafayette, Indiana 47907, U.S.A.

\begin{abstract}
Summary. The activities of phosphofructokinase, pyruvate kinase, citrate synthase and creatine kinase were determined in blastocysts from rabbits at $144 \mathrm{~h}$ post coitum and in similar blastocysts cultured for $24 \mathrm{~h}$ with or without oestradiol- $17 \beta(1 \mu \mathrm{g} / \mathrm{ml})$. There was a significant increase in all the enzymes during the 24 -h culture period but oestradiol had no effect.
\end{abstract}

\section{Introduction}

In the preimplantation rabbit blastocyst the glycolytic pathway of Embden-Mayerhof and the tricarboxylic acid (TCA) cycle of Krebs are considered to be the major sources of energy supply and of the intermediates required for biosynthetic activities and maintenance of blastocyst morphology (Fridhandler, 1961; Fridhandler, Wastila \& Palmer, 1967). Brinster (1971) has investigated the activity of phosphofructokinase, a key enzyme of glycolysis, in mouse preimplantation embryos, but we know of no other studies on the activity of regulatory enzymes of carbohydrate and energy metabolism in mammalian preimplantation embryos. We have therefore studied the activity of some of the enzymes involved in carbohydrate and energy metabolism in rabbit blastocysts in vitro.

\section{Materials and Methods}

Adult virgin female domestic rabbits were induced to superovulate (Kennelly \& Foote, 1965) by injecting them subcutaneously with $0.1 \mathrm{mg}$ FSH (Sigma) in $1 \mathrm{ml}$ saline twice daily for 3 consecutive days; on the morning of the 4th day, they were mated with two fertile bucks in rapid succession, and then injected intravenously with 25 i.u. hCG (Antuitrin-'S'; Parke-Davis) in $0.5 \mathrm{ml}$ saline. The females were killed $144 \mathrm{~h}$ post coitum (Day 6) and blastocysts were recovered by flushing the uteri with chilled saline $(0 \cdot 154 \mathrm{M}-\mathrm{NaCl})$ or TC-199 medium (at room temperature) supplemented with $4 \mathrm{mg}$ bovine serum albumin (BSA, Sigma)/ml. The blastocysts were washed twice with the same solution as used for their recovery, their diameters were recorded, and they were then divided into three groups. Group 1 blastocysts were those recovered in chilled saline and they were frozen immediately at $-80^{\circ} \mathrm{C}$. The blastocysts in Group 2 were cultured in $5 \mathrm{ml} \mathrm{TC}-199$ medium in a $10-\mathrm{ml}$ capacity Erlenmeyer flask which was placed in a Dubnoff metabolic shaking incubator: there were 8-12 blastocysts/flask and they were incubated for $24 \mathrm{~h}$ at $37^{\circ} \mathrm{C}$ under a gas phase of $95 \%$ air $+5 \% \mathrm{CO}_{2}$. The blastocysts in Group 3 were treated in the same way as those in Group 2, but $5 \mu \mathrm{g}$ oestradiol-17 $\beta$ (Sigma) dissolved in $0.05 \mathrm{ml} 70 \%$ ethanol were added to each flask. The same volume of ethanol (without oestradiol) was added to each flask in Group 2. After culture, the diameters and the general appearance of the blastocysts were checked under a stereoscopic microscope. The blastocysts were

* Reprint requests to S. K. Dey.

If Present address: Department of Physiology, All India Institute of Medical Science, Ansari Nagar, New Delhi110016 . India. 
then washed in cold saline, frozen, and kept at $-80^{\circ} \mathrm{C}$ until assay for enzyme activity. The enzymes studied were (a) phosphofructokinase (EC 2.7.1.11) and pyruvate kinase (EC 2.7.1.40), which are regulatory enzymes of the glycolytic pathway (Passonneau \& Lowry, 1964; Weber, Singhal, Stamm, Fisher \& Mentendiek, 1964), (b) citrate synthase (EC 4.1.3.7), a regulatory enzyme of the TCA cycle (Hathaway \& Atkinson, 1965), and (c) creatine kinase (EC 2.7.3.2), which is involved in energy metabolism.

Groups of 8-11 blastocysts were transferred into a small plastic tube containing $1 \mathrm{ml} 50 \mathrm{~mm}$ $\mathrm{KPO}_{4}$ buffer, $\mathrm{pH} 7 \cdot 4$. The blastocysts were sonicated for two 5-sec bursts separated by a short cooling period. Additional sonication did not increase the activity of any of the enzymes. An aliquot from each tube was used for assay of the activity of each enzyme.

Phosphofructokinase activity was determined according to the method of Sols \& Salas (1966). In brief, the reaction in the forward direction was assayed by coupling with aldolase, triosephosphate isomerase and glycerophosphate dehydrogenase. The initial rate of oxidation of $\mathrm{NADH}+\mathrm{H}^{+}$was measured at $340 \mathrm{~nm}$. Each mole of fructose-1,6-diphosphate formed by phosphofructokinase led to the oxidation of $2 \mathrm{~mol} \mathrm{NADH}+\mathrm{H}^{+}$. One $\mathrm{mU}$ of phosphofructokinase catalysed the conversion of $1 \mathrm{nmol}$ fructose-6-phosphate to fructose-1,6-diphosphate/min.

Pyruvate kinase activity was assayed by the method of Bücher \& Pfleiderer (1955). The reaction in the forward direction was measured by coupling with lactic dehydrogenase and the initial rate of oxidation of $\mathrm{NADH}+\mathrm{H}^{+}$was measured at $340 \mathrm{~nm}$. Each mole of pyruvate formed by pyruvate kinase caused oxidation of $1 \mathrm{~mol} \mathrm{NADH}+\mathrm{H}^{+}$. One $\mathrm{mU}$ of pyruvate kinase catalysed the conversion of $1 \mathrm{nmol}$ phosphoenolpyruvate to pyruvate/min.

Citrate synthase activity was determined by measuring the initial velocity of CoA formation at $412 \mathrm{~nm}$ by the 5,5-dithio-2-nitrobenzoate method as described by Srere, Brazil \& Gonen (1963). The molar absorbancy index for mercaptide ion formed is 13600 . The reaction was initiated by the addition of oxaloacetic acid and the preparation of acetyl CoA was based on the procedure of Simon $\&$ Shemin (1953). One $\mathrm{mU}$ of citrate synthase catalysed the liberation of $1 \mathrm{nmol} \mathrm{CoA}-\mathrm{SH} / \mathrm{min}$.

Creatine kinase activity was determined by the procedure of Rosalki (1967) as modified by Bergmeyer (1974). In short, the reaction in the reverse direction was assayed by coupling with hexokinase and glucose-6-phosphate dehydrogenase. The initial rate of $\mathrm{NADPH}+\mathrm{H}^{+}$formation was measured at $340 \mathrm{~nm}$. Each mole of creatine formed led to the reduction of $1 \mathrm{~mol}$ of NADP . One $\mathrm{mU}$ of creatine kinase catalysed the conversion of $1 \mathrm{nmol}$ of creatine phosphate to creatine $/ \mathrm{min}$.

All measurements were carried out at $25^{\circ} \mathrm{C}$ in a Beckman 25 spectrophotometer with a recorder attachment. The activity of the enzymes was expressed as $\mathrm{mU} /$ blastocyst rather than as units/mg protein, because blastocysts can accumulate BSA from the culture medium and thus affect their protein concentration (Beier \& Maurer, 1975). Similarly, the activity is not expressed as $\mathrm{mU}$ per unit-volume or per wet weight of the blastocyst because of the large accumulation of fluid which occurs when the unattached blastocyst expands.

\section{Results}

The blastocysts in Groups 2 and 3 appeared normal after culture and their volumes had increased (Table 1). The enzyme activities of the blastocysts in Groups 2 and 3 were all significantly higher than those of the Group-1 blastocysts but did not differ significantly from each other (Table 1).

\section{Discussion}

Changes in the enzymes studied should reflect the involvement of particular synthetic pathways. The demonstration of phosphofructokinase, pyruvate kinase and citrate synthase confirms the existence of the glycolytic-TCA cycle in the rabbit blastocyst (Fridhandler, 1961; Fridhandier et al., 1967). The significant increase in the activity of these enzymes in the blastocysts cultured for $24 \mathrm{~h}$ shows that these rate-limiting enzymes were functional. 
Table 1. Volumes and enzyme activities (mean \pm s.e.m.) of Day-6 rabbit blastocysts at the time of recovery (Group 1) and after culture for $24 \mathrm{~h}$ in the absence (Group 2) or presence (Group 3) of oestradiol-17 $\beta$ in the medium

\begin{tabular}{lccc}
\hline & Group 1 (3) & Group 2 (4) & Group 3 (4) \\
\hline Volume $\left(\mathrm{mm}^{3}\right)$ & $20.96 \pm 2.03$ & $55.89 \pm 2 \cdot 86^{*}$ & $50.21 \pm 5.44^{*}$ \\
Enzyme activity (mU/blastocyst) & & & \\
$\quad$ Citrate synthase & $2.55 \pm 0.08$ & $5 \cdot 39 \pm 0.52^{*}$ & $5.61 \pm 0.14^{*}$ \\
Creatine kinase & $19.27 \pm 2.06$ & $67.84 \pm 3 \cdot 20^{*}$ & $68.61 \pm 2.64^{*}$ \\
Pyruvate kinase & $0.77 \pm 0.01$ & $1.98 \pm 0 \cdot 18^{*}$ & $2.06 \pm 0.06^{*}$ \\
Phosphofructokinase & $0.029 \pm 0.008$ & $0.085 \pm 0.004^{*}$ & $0.087 \pm 0.001^{*}$ \\
\hline
\end{tabular}

Numbers in parentheses indicate the number of experiments; there were 8-11 blastocysts in each experiment.

* These values were significantly different from the corresponding values in Group $1, P<0.01$ (Student's $t$ test).

The new observation of the present work is the demonstration of creatine kinase activity in the rabbit blastocyst. This enzyme catalyses the reaction ADP + creatine phosphate $\rightleftharpoons$ ATP + creatine and thus makes available a substantial reserve source of ATP. The relatively high activity of creatine kinase in Day-6 rabbit blastocysts could be important as a source of high-energy phosphate bonds.

The significant increases in the activity of the three enzymes of the glycolytic-TCA cycle and creatine kinase in rabbit blastocysts during the 24-h culture period suggest that, during this period of rapid growth, part of the energy supplied is used and the remainder is stored. Brooks \& LutwakMann (1971) showed that the ATP + ADP content doubles every $9 \mathrm{~h}$ in Day-5 and Day-6 rabbit blastocysts. The generation of ATP via the glycolytic-TCA cycle and from creatine phosphate stores may be necessary for any sudden demand for energy, e.g. during shedding of zona pellucida or at implantation.

Phosphofructokinase and pyruvate kinase activity can be induced in the uteri of ovariectomized rats by oestrogenic hormones (Singhal, Valadares \& Ling, 1967; De Asua, Rozengurt \& Carminatti, 1968), but we found no effect of oestradiol on the enzyme activities studied. RNA synthesis in mouse preimplantation embryos was not altered by various concentrations of oestradiol in the culture medium (Warner \& Tollefson, 1977). It is possible that a combination of oestradiol and progesterone or other steroids is needed to affect these enzymes in cultured blastocysts, and uterine or serum factors in the culture medium could also be important (El-Banna \& Daniel, 1972; Roblero \& Izquierdo, 1976). It has been suggested that steroid hormones must bind to carrier proteins to be transported to the inside of the embryo before they can exert an embryotrophic effect (El-Banna \& Daniel, 1972; Fowler, Johnson, Walters \& Eager, 1977), and uterine-specific and other proteins have been shown to bind steroids and penetrate rabbit blastocysts (Beier, 1976). However, blastocysts may themselves produce steroids (Dickmann, Dey \& Sen Gupta, 1976) and so be unresponsive to exogenous steroids.

This study was supported in part by grants from NIH (1-RO1HD-08644-01Al) and from the National Foundation (1-406). We thank Mrs Linda Fischer for statistical analysis and Eleanor Colasanto for typing the manuscript.

\section{References}

BEIER, H.M. (1976) Uteroglobin and related biochemical changes in the reproductive tract during early pregnancy in the rabbit. J. Reprod. Fert., Suppl. 25, 53-69.

Beier, H.M. \& Maurer, R.R. (1975) Uteroglobin and other proteins in rabbit blastocyst fiuid after development in vivo and in vitro. Cell Tiss. Res. 159, 1-10.

Bergmeyer, H.U. (1974) Determination with creatine phosphate as substrate. In Methods of Enzymatic Analysis, pp. 789-793. Ed. H. U. Bergmeyer. Academic Press, New York.

BRINSTER, R.L. (1971) Phosphofructokinase activity in the preimplantation mouse embryo. Wilhelm Roux Arch. Entw Mech. Org. 166, 300-302.

Brooks, D.E. \& Lutwak-ManN, C. (1971) Content of ATP and ADP in rabbit blastocysts. Nature, Lond. 229, 202-203.

Bücher, T. \& Pfleiderer, G. (1955) Pyruvate kinase from muscle. In Methods in Enzymology, Vol. 1, pp. 435-440. Eds S. P. Colowick \& N. O. Kaplan. Academic Press, New York.

De Asua, L.J., Rozengurt, E. \& Carminatti, H. (1968) Oestradiol induction of pyruvate kinase in the rat uterus. Biochim. biophys. Acta 170, 254-262. 
Dickmann, Z., Dey, S.K. \& Sen Gupta, J. (1976) A new concept : control of early pregnancy by steroid hormones originating in the preimplantation embryo. Vitams Horm. 34, 215-242.

Ez-Banna, A.A. \& Daniel, J.C., JR, (1972) Stimulation of rabbit blastocysts in vitro by progesterone and uterine proteins in combination. Fert. Steril. 23, 101-104.

Fowler, R.E., Johnson, M.H., WALters, D.E. \& EAGER, D.D. (1977) The progesterone content of rabbit uterine flushings. $J$. Reprod. Fert. 50, 301-308.

Fridhandler, L. (1961) Pathways of glucose metabolism in fertilized rabbit ova at various preimplantation stages. Expl Cell Res. 22, 303-316.

Fridhandler, L., Wastila, W.B. \& Palmer, W.M. (1967) The role of glucose in metabolism of the developing mammalian preimplantation conceptus. Fert. Steril. 18, 819-830.

Hathaway, J.A. \& AtKinson, D.E. (1965) Kinetics of regulatory enzymes: effect of adenosine triphosphate on yeast citrate synthase. Biochim. Biophys. Res. Commun. 20, 661-665.

KenNelly, J.J. \& Foote, R.H. (1965) Superovulatory response of pre- and postpubertal rabbits to commercially available gonadotrophins. J. Reprod. Fert. 9, 177-188.

Passonneau, J.V. \& Lowry, O.H. (1964) The role of phosphofructokinase in metabolic regulation. In
Advances in Enzyme Regulation, Vol. 2, pp. 265-274. Ed. G. Weber. MacMillan, New York.

Roblero, L. \& Izquierdo, L. (1976) Effect of progesterone on the cleavage rate of mouse embryos in vitro. J. Reprod. Fert. 46, 475-476.

Rosalki, S.B. (1967) An improved procedure for serum creatine phosphokinase determination. J. Lab. clin. Med. 69, 696-705.

Simon, E.J. \& Shemin, D.J. (1953) The preparation of S-Succinyl Coenzyme A.J. Am. Chem. Soc. 75, 2520.

Singhal, R.L., Valadares, J.R.E. \& Ling, G.M. (1967) Metabolic control mechanisms in mammalian systems. I. Hormonal induction of phosphofructokinase in the rat uterus. J. biol. Chem. 242, 2593-2598.

Sols, A. \& Salas, M.L. (1966) Phosphofructokinase. In Methods in Enzymology, Vol. IX, pp. 436-442. Ed. W. A. Wood. Academic Press, New York.

Srere, P., Brazil, H. \& Gonen, L. (1963) The citrate condensing enzyme of pigeon breast and moth flight muscle. Acta chem. scand. 17, S129-134.

Warner, C.M. \& TOllefson, C.M. (1977) The effect of estradiol on RNA synthesis in preimplantation mouse embryos cultured in vitro. Biol. Reprod. 16, 627-632.

Weber, G., Singhal, R.L., Stamm, N.B., Fisher, E.A. \& Mentendiek, M.A. (1964) Regulation of enzymes involved in gluconeogenesis. In Advances in Enzyme Regulation, Vol. 2, pp. 1-38. Ed. G. Weber. MacMillan, New York.

Received 7 September 1977 